\title{
EVALUATION OF THE EFFICACY OF TWO BIOAGENTS AGAINST THE COTTON LEAFWORM, SPODOPTERA LITTORALIS (BOISD.), USING MOLECULAR CHARACTERIZATION TECHNIQUES
}

\author{
MARWA M.A. EL-SABAGH* \\ Plant Protection Research Institute, ARC, Dokki, Giza, Egypt \\ *Corresponding Author mail: ferfer2008@hotmail.com \\ (Manuscript received 16 June 2015)

\begin{abstract}
$\mathrm{M}$ olecular studies have been carried out on $6^{\text {th }}$ instar larvae of Spodoptera littoralis which treated in $2^{\text {nd }}$ larval instars with $\mathrm{LC}_{50}$ of two bioagents named Viruset and Protecto at $1 \times 10^{3} \mathrm{PIBs} / \mathrm{ml}$ and $3.2 \times 10^{2} \mathrm{IU} / \mathrm{ml}$., respectively. Four random primers were used in this study to generate a fragmenting treated samples and control. The numbers of unique and common fragments generated by using these primers (OPO1, OPO2, OPO3 and $\mathrm{OPO} 4$ ) was recorded. It has been found that primer OPO4 was the most powerful one in generating a unique informative fragmenting pattern; it gives 4 specific unique fragments. While the fragmenting pattern.
\end{abstract} \\ pattern as a tool to investigate the molecular differences between \\ primer OPO1 was the poorest one in generating an informative
}

\section{INTRODUCTION}

The Egyptian cotton leafworm, S. littoralis, is an important pest in Egypt and other countries in Africa and Asia causes extensive economic losses in many cultivated crops (Frank et al., 1990). The extensive use of chemical for controlling S. littoralis caused negative side effects on humans, other living organisms and environment (Chantelli-Forti et al., 1993 and Chaudhuri et al., 1999). Furthermore, this insect acquired resistance to various classes of insecticides (Denholm et al., 1998). The problems and hazards that have arisen as a result of using conventional insecticides were incentives for the search of alternative control agents. Microbial control agents are a primary means of biological control for insect pests. The use of microbial control agents is targeted for a particular pest species. The entomopathogens that have been mostly used in biological control include representatives of bacteria, fungi, viruses, nematodes and protozoa (Dent, 2000). This work was designed to study the differences between treated and untreated larvae using the RAPD-PCR techniques. El Gohary et al. (2000) and Abdel-Wahed et al (2013). 


\section{MATERIALS AND METHODS}

\section{1-Rearing technique of the Egyptian cotton leafworm, S. littoralis:}

The original insect culture was obtained from the Cotton Leafworm Division, at Plant Protection Research Institute. Newly hatched larvae were transferred to clean glass jars covered with muslin held in position with rubber fragments and incubated under laboratory condition at $27^{\circ} \pm 2^{\circ} \mathrm{C}, 60 \pm 5 \% \mathrm{RH}$, and 8:16 LD photoperiod. They were fed on castor oil leaves and examined daily. After pupation, pupae were collected; sexed and emerged moths were placed in pairs in breeding glass jars. These jars were supplied with leaves of Tafla, Nerium oleander (L.) as an oviposition site.

\section{2-The tested compounds:-}

The potency of two bioagents was evaluated for their effect on S. littoralis larvae as following:

2.1. Spodoptera littoralis Nuclear Polyhydrosis Virus (SLNPV), with the trade name: Viruset ${ }^{\circledR}$.

2.2. Bacillus thuringiensis var. kurstaki with the trade name Protecto ${ }^{\circledR}$.

These two microbial agents were obtained from Insect Pathogen Production Unit Plant Protection Research Institute.

\section{3- Bioassay:-}

The insecticidal activity of the two bioagents was assessed on newly ecdysed $2^{\text {nd }}$ instars of $S$. littoralis larvae as following:

a) Viruset: A series of dilution were prepared from $1 \mathrm{gm}$ of the product obtained as a wettable powder, $1 \times 10,1 \times 10^{2}, 1 \times 10^{3}, 1 \times 10^{4}, 1 \times 10^{5}, 1 \times 10^{6}$ and $1 \times 10^{7} \mathrm{PIBs} / \mathrm{ml}$. (PIBs= Polyhedral Inclusion Bodies)

b) Protecto The following dilutions were prepared from $1 \mathrm{gm}$ of the product also obtained as a wettable powder, $3.2,3.2 \times 10,3.2 \times 10^{2}, 3.2 \times 10^{3}, 3.2 \times 10^{4}$ and $3.2 \times 10^{5} \mathrm{IU} / \mathrm{ml}$. (IU= International Unit).

Treatment of larvae was conducted by the leaf dipping technique using a fresh castor oil leaves Ricinus communis $(\mathrm{L})$ which were cleaned and immersed for 10 seconds in one of the prepared concentrations or dilutions of each one tested compound. The treated leaves were left to dry at room temperature before being offered to newly ecdysed $2^{\text {nd }}$ instar $S$. littoralis larvae. Larvae were offered treated leaves for $48 \mathrm{hr}$ and subsequently larvae were fed on untreated castor oil leaves for the following duration of the larval stage. Each treatment comprised 20 larvae and was replicated three times. The same number of larvae was considered as a control while larvae were offered castor oil leaves dipped in water. 


\section{4- The Molecular study:-}

The DNA was extracted according to the method of Sambrook et al. (1989). Before any analysis, it was important to determine the concentration and purity of isolated DNA; this was carried out by estimating UV absorbance at wave length of 260 and $280 \mathrm{~nm}$ using a spectrophotometer. DNA was subjected to PCR in order to generate the fragmenting profile. The random primers used were OPO1, OPO2, OPO3 and OPO4. Reactions were carried out in a thermocycler (Progeny 30, Techno, Cambridge Ltd. Dux ford Cambridge, UK). The PCR profile was as follows: $94{ }^{\circ} \mathrm{C}$ for 5 $\min , 94^{\circ} \mathrm{C}$ for $1 \mathrm{~min}, 40^{\circ} \mathrm{C}$ for $1 \mathrm{~min}, 72^{\circ} \mathrm{C}$ for $2 \mathrm{~min}$, and final extension at $72{ }^{\circ} \mathrm{C}$ for $7 \mathrm{~min}$. Then the PCR reaction was kept at $4{ }^{\circ} \mathrm{C}$ over night, till migration on agrose was occurred.

\begin{tabular}{|c|c|c|}
\hline No & Primer & Sequence \\
\hline 1 & OPO1 & 5'- GGC ACG TAA G -3' \\
\hline 2 & OPO2 & 5'- ACG TAG CGT C -3' \\
\hline 3 & OPO3 & 5'- CTG TTG CTA C -3' \\
\hline 4 & OPO4 & 5'- AAG TCC GCT C -3' \\
\hline
\end{tabular}

The gel was prepared with wells into which the DNA fragments are added and subemerged under an electrolyte buffer solution between a positive and a negative electrode. The DNA fragments are negatively charged so the wells containing them are placed closest to the negative electrode. When the current is turned on the DNA moves through the pores in the gel towards the positive electrode. PCR- DNA marker was used to determine the molecular weight of each fragment. The shorter fragments move faster because they are able to move through the pores of the gel more easily, whereas the longer DNA fragments move more slowly through the pores (Hurlbert, 1999).

\section{5- Statistical analysis}

1- Results were presented graphically as log/probit regression lines, and toxicity LC $_{50}$ and LC $_{90}$ values as well as the slope according to Finney, (1971) using "LdPLine ${ }^{\circledR "}$ software.

2- DNA sequences were analyzed using version 6 of the Gel-Pro Analyzer package of genetics computer program. 


\section{RESULTS AND DISCUSSION}

\section{1- Bioassay Test:}

Data in Table (1) cleared that the efficiency of the two tested compounds, Viruset (Spodoptera littoralis Nuclear Polyhydrosis Virus, SLNPV) and Protecto (Bacillus thuringiensis var. kurstakl), were evaluated on $2^{\text {nd }}$ instar larvae of $S$. littoralis (Boisd.). Viruset toxicity had an effect on $2^{\text {nd }}$ instar larvae giving the $\mathrm{LC}_{90}$ and $\mathrm{LC}_{50} 1 \times 10^{7}$ and $1 \times 10^{3} \mathrm{PIBs} / \mathrm{ml}$. Meanwhile the $\mathrm{LC}_{90}$ and $\mathrm{LC}_{50}$ of Protecto were $3.2 \times 10^{5}$ and $3.2 \times 10^{2}$ IU/ml., respectively. Our results was agreed with those reported by Abdel-Aziz, (2007) and Abdel- Wahed, et al. (2011).

Table 1 . Susceptibility of $S$. littoralis $2^{\text {nd }}$ instar larvae to Viruset and Protecto

\begin{tabular}{|c|c|c|c|c|}
\hline Compound & Unit & $\mathrm{LC}_{90}$ & $\mathrm{LC}_{50}$ & Slope \\
\hline Viruset & PIBs/ml & $1 \times 10^{7}$ & $1 \times 10^{3}$ & $1.4599 \pm 0.2411$ \\
\hline Protecto & $\mathrm{IU} / \mathrm{ml}$. & $3.2 \times 10^{5}$ & $3.2 \times 10^{2}$ & $1.6531 \pm 0.2165$ \\
\hline
\end{tabular}

\section{2- Molecular Studies:}

This study has been carried out on $6^{\text {th }}$ instar larvae of $S$. littoralis which treated in $2^{\text {nd }}$ instar larvae with $\mathrm{LC}_{50}$ of Viruset and Protecto at $1 \times 10^{3} \mathrm{PIBs} / \mathrm{ml}$. and $3.2 \times 10^{2} \mathrm{IU} / \mathrm{ml}$., respectively.

Four random primers were used (OPO1, OPO2, OPO3 and OPO4) to generate the specific by which an informative conclusion could be summarized. The four primers used are shown in table (2) and fig. (1) along with their sequences.

Using primer OPO1, a distinguishing pattern was obtained when using a control, Viruset- treated, and Protecto-treated larvae as a source of DNA.

In this primer, the treatment with Viruset induced the generation of a fragment with size of $979 \mathrm{bp}$. This fragment was absent in both control and Protectotreatment larvae, the same finding was found in Viruset and Protecto regarding the induction of a fragment with a size of 452 bp and also this fragment was absent in control. On other hand, the missing fragments were noticed in both Viruset and Protecto treatments while it was present in control with size of $251 \mathrm{bp}$.

In primer $\mathrm{OPO} 2$, the treatment with tested compounds resulted in the presence of two fragment with size of 350 and 274 bp in casse of Protecto treatment while, this fragment was absent in control and Viruset treatments that may clarify the action of Protecto. The same findings was shown in fragments with size of 612,500 and 408 bp that present in both control and Protecto while it was absent in Viruset treatment. On other hand, the missing fragments were noticed in both Viruset and Protecto treatments while it was present only in control with size of $770 \mathrm{bp}$. On the 
other hand, fragments with size 1694, 1261 and 1065 bp were present in both control and Viruset treatments but it was absent in Protecto treatment.

In primer $\mathrm{OPO}$, the treatment with Protecto resulted in the absence of a fragment which was present in both control and Viruset treatments; this absence may be attributed to the treatment with Protecto. However, for the same treatment a fragment with size 576 bp was noticed while it was absent in both control and Viruset treatments. One fragment with size 358 bp was absent in the treatment in both Viruset and Protecto treatments and a fragment was observed in the control. However, the treatment with Protecto led to the absence of a fragment and this fragment was present in both control and Viruset treatments with size of $959 \mathrm{bp}$.

In primer OPO4, three fragments were noticed due to the treatment with Viruset, while, the same molecular size fragments were present in both control and Protecto treatment with size $(1461,1021,839,431 \mathrm{bp})$.

On the other hand, a specific unique fragment was obtained (at molecular size of 859 and $510 \mathrm{bp}$ ) due to the treatment with Viruset. While this fragment was absent in the control and Protecto treatments.

RAPD-PCR technique clarified the DNA diversity among the $6^{\text {th }}$ instar larvae of S. littoralis which was treated with $\mathrm{LC}_{50}$ of Viruset and Protecto. 43 DNA fragments were detected using four random primers. 17 fragments were common in treated and untreated larvae of $S$. littoralis; they represent $39.5 \%$ of all detected fragments. On the other hand the RAPD-PCR technique shows 14 polymorphic amplified fragments represented $32.5 \%$. This ratio is due to treatment with Viruset and Protecto. Treated and untreated larvae showed 12 unique fragments that represented $27.9 \%$ of all detected fragments (Table 3). Finally, this study confirmed that Protecto was more effective on DNA generated than Viruset.

The previous results showed that primers number (OPO4) was the powerful one in generating a unique informative fragmenting pattern; it gave four specific unique fragments. While the primer OPO1 was the poorest one in generating an informative fragmenting pattern, it gives two specific unique fragments. Our results was agreed with those reported by El Gohary et al. (2000) who reported that the DNA fragments varied in intensity and ranged in size from (140-1500 bp) and (196 -1060 bp), respectively. Abd EL- Aziz, (2006) reported in his study that both proteins and RAPD-PCR markers could be used to give estimations of genetic variation and differentiation of different treated and untreated $S$. littoralis larvae with the selected bacterial strains MVPII and the best primers that can be used for developing a genetic marker to differentiate between the different strains were OPB-3 and OPA-18. AbdelGhany (2011) generate a banding pattern as a tool to investigate the molecular 
differences between different treatments botanical extracts castor oil, gossypol on $S$. littoralis larvae. The numbers of unique and common bands generated by using these primers ( $\mathrm{C} 1, \mathrm{C} 4, \mathrm{C} 10, \mathrm{C} 13, \mathrm{C} 15, \mathrm{O} 5, \mathrm{O} 7, \mathrm{O} 14$, and $\mathrm{O} 10)$ was recorded. It has been found that primers $010, \mathrm{C} 4$ were the most powerful one in generating a unique informative banding pattern.

Molecular genetic fingerprinting was carried out using 5 random primers on $2^{\text {nd }}$ instar larvae of $S$. littoralis which treated with $B t$ and IGR. The obtained data suggested that primer OPO2 was the most powerful primers in regarding generating specific unique band. While the primer OPO4 was the poorest one in generating an informative banding pattern. Abdel- Wahed et al (2013).

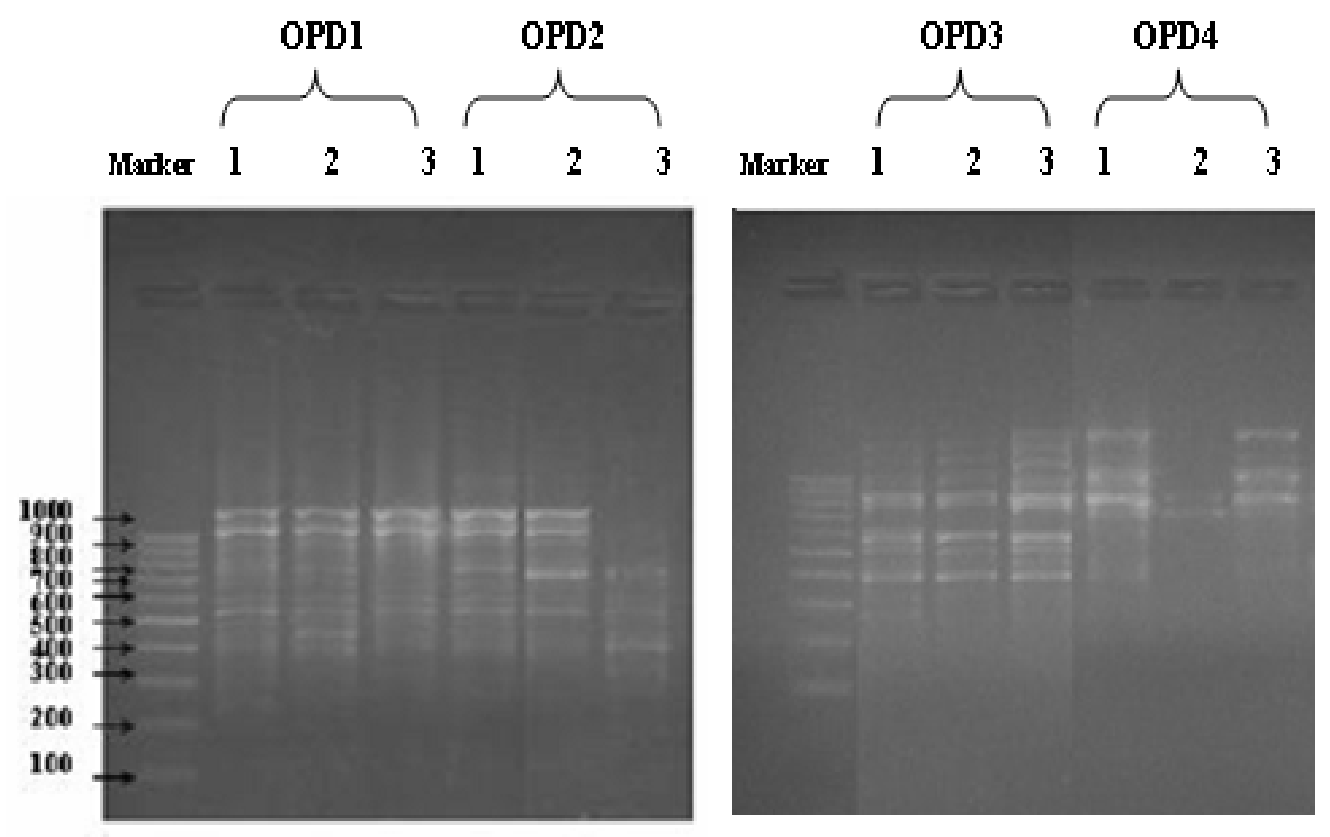

Fig. 1. Molecular fingerprinting using RAPD DNA for pattern for samples treated with Viruset, Protecto and control.
M=Marker
$1=$ Control
2=Viruset
$3=$ Protecto 
Table 2. RAPD-PCR Products in $6^{\text {th }}$ instar larvae of Spodoptera littoralis which treated in $2^{\text {nd }}$ instar larvae with $\mathrm{LC}_{50}$ of Viruset and Protecto compared with control using random primers.

\begin{tabular}{|c|c|c|c|c|c|c|c|c|c|c|c|c|c|c|c|c|c|c|c|c|}
\hline \multirow{3}{*}{$\begin{array}{l}\text { Lanes } \\
\text { Rows } \\
\end{array}$} & \multicolumn{9}{|c|}{ Primer 1: OPO1 } & \multicolumn{9}{|c|}{ Primer $2: \mathrm{OPO} 2$} & \multirow{2}{*}{\multicolumn{2}{|c|}{ Marker }} \\
\hline & \multicolumn{3}{|c|}{ Control } & \multicolumn{3}{|c|}{ Viruset } & \multicolumn{3}{|c|}{ Protecto } & \multicolumn{3}{|c|}{ Control } & \multicolumn{3}{|c|}{ Viruset } & \multicolumn{3}{|c|}{ Protecto } & & \\
\hline & M.w & Amount & $\mathrm{Rf}$ & M.w & amount & $\mathrm{Rf}$ & M.w & Amount & $\mathrm{Rf}$ & M.w & amount & $\mathrm{Rf}$ & M.w & Amount & $\mathrm{Rf}$ & M.w & amount & $\mathrm{Rf}$ & M.w & amount \\
\hline $\mathrm{r} 1$ & & & & & & & & & & 1694 & 8.687 & 0.514 & 1694 & 10.248 & 0.564 & & & & & \\
\hline r2 & 1288 & 11.774 & 0.561 & 1288 & 14.921 & 0.561 & 1288 & 12.851 & 0.561 & 1261 & 13.384 & 0.564 & 1261 & 16.824 & 0.593 & & & & & \\
\hline r3 & 1088 & 12.943 & 0.589 & 1088 & 12.732 & 0.589 & 1065 & 15.08 & 0.593 & 1065 & 18.846 & 0.593 & 1065 & 10.631 & 0.607 & & & & 1000 & 8.936 \\
\hline r4 & & & & 979 & 10.524 & 0.607 & & & & & & & & & & & & & 900 & 5.779 \\
\hline r5 & 785 & 14.526 & 0.645 & 785 & 15.311 & 0.645 & 849 & 13.082 & 0.631 & 770 & 12.638 & 0.648 & & & & & & & 800 & 6.888 \\
\hline r6 & 713 & 8.342 & 0.662 & & & & 713 & 9.681 & 0.662 & 687 & 9.303 & 0.669 & 727 & 23.352 & 0.659 & 741 & 23.33 & 0.655 & 700 & 7.85 \\
\hline r7 & 612 & 8.303 & 0.69 & 624 & 11.632 & 0.686 & 600 & 6.956 & 0.693 & 612 & 6.707 & 0.69 & & & & 600 & 9.897 & 0.693 & 600 & 9.834 \\
\hline r8 & 548 & 8.665 & 0.711 & 548 & 13.564 & 0.711 & 548 & 16.489 & 0.711 & 548 & 9.442 & 0.711 & 548 & 16.279 & 0.711 & 538 & 10.131 & 0.714 & & \\
\hline r9 & & & & & & & & & & 500 & 5.136 & 0.729 & & & & 509 & 8.204 & 0.725 & 500 & 11.447 \\
\hline $\mathrm{r} 10$ & & & & 452 & 10.309 & 0.746 & 452 & 7.844 & 0.746 & 452 & 6.348 & 0.746 & 434 & 22.832 & 0.754 & & & & & \\
\hline $\mathrm{r} 11$ & 408 & 14.58 & 0.764 & 400 & 11.021 & 0.768 & 400 & 9.839 & 0.768 & 408 & 9.875 & 0.764 & & & & 400 & 21.822 & 0.768 & 400 & 11.639 \\
\hline $\mathrm{r} 12$ & 324 & 11.88 & 0.807 & & & & 343 & 8.214 & 0.796 & & & & & & & 350 & 18.137 & 0.793 & & \\
\hline $\mathrm{r} 13$ & & & & & & & & & & & & & & & & & & & 300 & 13.479 \\
\hline r14 & 251 & 9.025 & 0.85 & & & & & & & & & & & & & 274 & 8.483 & 0.836 & & \\
\hline $\mathrm{r} 15$ & & & & & & & & & & & & & & & & & & & 200 & 11.713 \\
\hline $\mathrm{r} 16$ & & & & & & & & & & & & & & & & & & & 100 & 12.437 \\
\hline $\mathrm{r} 17$ & & & & & & & & & & & & & & & & & & & & \\
\hline $\mathrm{r} 18$ & & & & & & & & & & & & & & & & & & & & \\
\hline
\end{tabular}


Continued Table (2) .............

\begin{tabular}{|c|c|c|c|c|c|c|c|c|c|c|c|c|c|c|c|c|c|c|c|c|}
\hline \multirow{3}{*}{$\begin{array}{l}\text { Lanes } \\
\text { Rows }\end{array}$} & \multicolumn{9}{|c|}{ Primer 3 : OPO3 } & \multicolumn{9}{|c|}{ Primer 4: OPO4 } & \multirow{2}{*}{\multicolumn{2}{|c|}{ Marker }} \\
\hline & \multicolumn{3}{|c|}{ Control } & \multicolumn{3}{|c|}{ Viruset } & \multicolumn{3}{|c|}{ Protecto } & \multicolumn{3}{|c|}{ Control } & \multicolumn{3}{|c|}{ Viruset } & \multicolumn{3}{|c|}{ Protecto } & & \\
\hline & M.w & Amount & $\mathrm{Rf}$ & M.w & amount & $\mathrm{Rf}$ & M.w & Amount & $\mathrm{Rf}$ & M.w & amount & $\mathrm{Rf}$ & M.w & amount & $\mathrm{Rf}$ & M.w & amount & $\mathrm{Rf}$ & M.w & amount \\
\hline r1 & & & & & & & 1730 & 9.552 & 0.15 & & & & & & & & & & & \\
\hline $\mathrm{r} 2$ & 1624 & 7.471 & 0.169 & 1658 & 9.821 & 0.163 & 1557 & 8.699 & 0.181 & & & & & & & & & & & \\
\hline r3 & 1431 & 9.116 & 0.206 & 1461 & 11.435 & 0.2 & 1372 & 10.504 & 0.219 & 1461 & 19.192 & 0.138 & & & & 1461 & 17.972 & 0.138 & & \\
\hline$r 4$ & 1235 & 7.751 & 0.25 & 1235 & 13.930 & 0.25 & 1209 & 10.803 & 0.256 & & & & & & & 1209 & 7.1509 & 0.194 & & \\
\hline r5 & & & & & & & & & & & & & & & & & & & & \\
\hline r6 & 1021 & 10.47 & 0.306 & 1043 & 12.352 & 0.3 & 1021 & 20.17 & 0.306 & 1021 & 17.974 & 0.244 & & & & 1021 & 19.612 & 0.244 & 1000 & 8.351 \\
\hline$r 7$ & 959 & 8.57 & 0.325 & 959 & 9.379 & 0.325 & & & & & & & 859 & 22.713 & 0.294 & & & & 900 & 4.89 \\
\hline$r 8$ & & & & & & & & & & 839 & 17.21 & 0.3 & & & & 839 & 20.326 & 0.3 & 800 & 7.282 \\
\hline r9 & 716 & 15.751 & 0.406 & 716 & 15.510 & 0.406 & 716 & 13.1661 & 0.406 & 719 & 10.406 & 0.338 & 719 & 25.304 & 0.338 & 700 & 15.027 & 0.344 & 700 & 7.182 \\
\hline r10 & 641 & 8.651 & 0.438 & 641 & 10.834 & 0.438 & 655 & 8.023 & 0.431 & 613 & 16.138 & 0.381 & & & & & & & & \\
\hline$r 11$ & & & & & & & 576 & 6.232 & 0.469 & & & & & & & & & & 600 & 8.299 \\
\hline$r 12$ & 510 & 20.8 & 0.506 & 510 & 16.923 & 0.506 & 510 & 12.857 & 0.506 & & & & 510 & 52.042 & 0.421 & & & & & \\
\hline $\mathrm{r} 13$ & & & & & & & & & & & & & & & & & & & 500 & 9.861 \\
\hline r14 & & & & & & & & & & 400 & 19.089 & 0.494 & & & & 431 & 20.011 & 0.475 & 400 & 13.214 \\
\hline $\mathrm{r} 15$ & 358 & 11.446 & 0.606 & & & & & & & & & & & & & & & & & \\
\hline$r 16$ & & & & & & & & & & & & & & & & & & & 300 & 15.3 \\
\hline$r 17$ & & & & & & & & & & & & & & & & & & & 200 & 11.508 \\
\hline $\mathrm{r} 18$ & & & & & & & & & & & & & & & & & & & 100 & 14.138 \\
\hline
\end{tabular}


Table 3. DNA diversity among S. littoralis treated with Viruset and Protecto using RAPD-PCR.

\begin{tabular}{|c|c|c|c|c|c|c|c|}
\hline \multirow{2}{*}{ Primers } & \multicolumn{4}{|c|}{ Polymorphism } & \multicolumn{3}{c|}{ Genetic markers (bp)* } \\
\cline { 2 - 8 } & TAF & MAF & PAF & Unique & Control & $\begin{array}{c}\text { Treated with } \\
\text { Viruset }\end{array}$ & $\begin{array}{c}\text { Treated with } \\
\text { Protecto }\end{array}$ \\
\hline OPO1 & 11 & 6 & 3 & 2 & 251 & 979 & - \\
\hline OPO2 & 12 & 3 & 6 & 3 & 770 & - & $350-274$ \\
\hline OPO3 & 11 & 7 & 1 & 3 & 358 & - & $1730-576$ \\
\hline OPO4 & 9 & 1 & 4 & 4 & 613 & $859-510$ & 1209 \\
\hline Total & 43 & 17 & 14 & 12 & 5 & 3 & 5 \\
\hline
\end{tabular}

bp-------------- size of genetic marker (unique).

TAF------------- total amplified fragments.

MAF------------ monomorphic amplified fragments (common).

PAF------------- polymorphic amplified fragments.

\section{REFERENCES}

1. Abd EL- Aziz, H. S. 2006. Toxicology and Genetics of Resistance to Some Bacterial Formulations in the Cotton Leafworm Spodoptera littoralis (Boisd.) (Lepidoptera : Noctiudae) Ph. D. Thesis, Fac. Science., Ain Shams Univ.

2. Abdel-Aziz, M. M. 2007. Controlling of the cotton leafworm, Spodoptera littoralis (Boisd.), by using environmentally safe (nontraditional) methods. M. Sc. Thesis, Institute of Environmental Studies and Research, Ain Shams University

3. Abdel-Ghany, S.E. 2011. Assessment of environmental hazardous and molecular characterization of controlling of Spodoptera littoralis (Bosid) by some plant extracts. M. Sc. Thesis, Institute of Environmental Studies and Research, Ain Shams University

4. Abdel- Wahed, M. S., F. A. Mariy, E. A. Abdel-All and M. M. Abdel-Aziz. 2011. The effect of certain biocontrol agent on same biological, biochemical and histological aspects of the cotton leaf worm, Spodoptera littoralis (Boisd.) (Lepidoptera: Noctuidae) Egypt, J.Agric.Res., 89 (2).431-444.

5. Abdel-Wahed, M. S.; S. M. El-Bermawy; K. A. El-Dougdoug; A. M. Mabrouk and M. M. Abdel-Aziz. 2013. Evaluation of The Efficacy of one Bioagent and an Insect Growth Regulator Against the Cotton Leafworm, Spodoptera littoralis (Boisd.), Using Molecular Characterization Technique. Egypt, J.Agric.Res, 91 (2): 525-538.

6. Chantelli-Forti, G.; M. Paolini; and P. Hrelia. 1993. Multiple end point procedure to evaluate risk from pesticides.Environ. Health Perspect. 101: 15-20. 
7. Chaudhuri, K.; S. Selvaraj; and A. Pal. 1999. Studies on the genotoxicity of endosulfan in bacterial systems. Mutat. Res. 439: 63-67.

8. Denholm, I. M.; T.J. Cahill; A. E. Dennehy and A. R. Horowitz (1998). Challenges with managing insecticide resistance in agricultural pests exemplified by the whitefly Bemisia tabaci. Phil. Trans. Royal. Soc. (London. B) 353 (1376): 17571767.

9. Dent, D. 2000. Biological control. In: Insect Pest Management. 2nd edition. London. CABI publishing. Ch. 6: 180-234 pp.

10. El-Gohary, E. A.; M. S. Salama; A. S. Abu Zeid and A. H. Kaschef. 2000. Molecular Approach for cast differentiation of the termite Kalotermes flavicollis (Fab.) .J.Egypt. Ger. Soc. Zool., Vol. 33 (E), Entomol., 357-377.

11. Finney, D. J. 1971. Probit Analysis, A statistical treatment of the sigmoid response curve, 7th Ed., Cambridge Univ. Press, Cambridge.

12. Frank, R.K.; H. E. Braun; B. D. Ripley and B. S. Clegy. 1990. Contamination of rural ponds with pesticides, 1971-1985. Ontario, Canada Bull. Environm. Contamin. Toxicol. 13: 771-817.

13. Hurlbert, R. E. 1999. Genetic engineering. Microbiology internet text. Science Hall Room 440 CA.

14. Sambrook, J. M.; E. F. Fritsch and T. U. Maniatis. 1989. Molecular Cloning: a laboratory manual. 2nd ed. N.Y., Cold Spring Harbor Laboratory, Cold Spring Harbor Laboratory Press,. 1659 p. ISBN 0-87969-309-6. 


\section{تقييم فاعلية مركبين حيويين ضد دودة ورق القطن باستخدام تقتية التوصيف الجزيئي}

مروة محمد محمود عبد العزيز الصباغ

$$
\text { معهر بحوث وقاية النباتات - مركز البحوث الزراعبة - دقي - جيزة - مصر. }
$$

اجريث هذه الدراسة علي يرقات العمر السادس لدوده ورق القطن التي عوملت في العمر

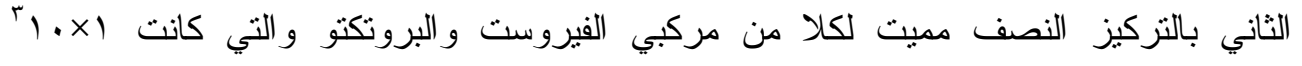

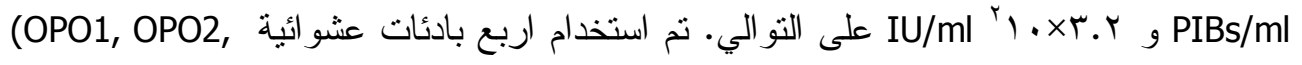

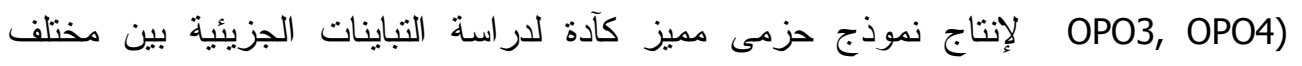

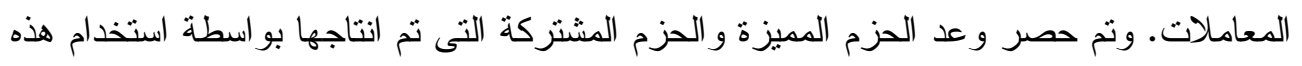

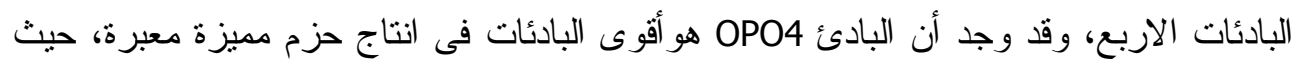

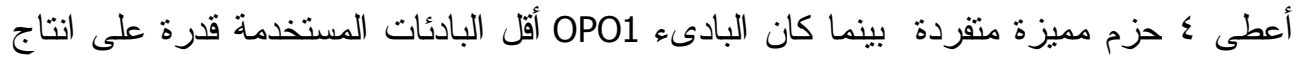

